\title{
A versatile flow channel for laboratory experiments with running water macroinvertebrates
}

\author{
by Andreas Frutiger, EAWAG, $\mathrm{CH}-8600$ Dübendorf \\ Manuscript received on $19^{\text {th }}$ october 1984
}

\begin{abstract}
Experiments with running water organisms should be conducted under running water conditions. A flow channel which has proved useful for long-term rearing of running water macroinvertebrates is described. Through its arena-shaped design and water jet drive, damage to drifting animals is practically excluded.
\end{abstract}

\section{Motivation}

The main difference between running water habitats and other aquatic ecosystems is the presence of a constant current. This constant, directed water flow fundamentally controls, as does gravitation with plankton, morphology, physiology and behaviour of those organisms permanently exposed to it [1]. In many cases, this has lead to a total dependency on current (rheosteny), particularly in regards to gas exchange during respiration, which excludes survival of these species in standing water. In this respect, rheophile individuals are particularly sensitive as they actively expose themselves to the current in order to satisfy their physiological requirements, without which they would soon cease to exist. However, even very weak current speeds, (a few $\mathrm{cm} / \mathrm{s}$ ), are sufficient to enable such rheostenic individuals as Rhithrogena sp. and Epeorus sp. (both Ephemeroptera: Heptageniidae) to survive in waters with only a few milligrams of oxygen per litre [1]. In turn, even the rheophobic species, which naturally avoid strong currents and reside below the first sediment layer, in the interstitial space, in backwaters or in moss will perish under total absence of current over a longer period of time. In many cases, the animals are physiologically dependent on current, especially during certain development stages, as for example the moulting stage (author's own experience with Dinocras cephalotes Curt., Plecoptera: Perlidae) or the pupal stage (for example Trichoptera, Malicky, personal communication).

Current exerts a constant stimulus on the mechanoreceptors of stream animals and is therefore of great importance in the behaviour and orientation of these animals. It is primarily the ability to react to current stimuli in an appropriate manner that enables the animals to choose habitats exposed to current. Since there are no chemical gradients locally in natural running waters, the benthic communities receive all chemical 
stimuli from "luff". It is therefore possible that rheostenic animals have lost their ability to perceive chemical gradients (i.e. their direction and gradients), and consequently, are dependent for orientation on a combination of chemical stimuli (quality and intensity) and current stimuli (direction). This point has not been verified, but it can be assumed that the absence of current seriously affects orientation (and thereby also behaviour) of stream animals.

As a result of this exposition comes the trivial, but continually ignored plea, that laboratory studies of stream-dwelling organisms should only be conducted in flow channels. If for any reason this is not possible, (for example if too much equipment is necessary), at least a few random tests must guarantee that current is only of minor importance in the question under investigation.

\section{Flow channel}

The channel presented in this study was developed and built for studies on the ecology of Dinocras cephalotes Curt. [3]. It has given good results and was also repeatedly used later [2]. It consists primarily of two identical arena-shaped channels of polyacryl glass of $25 \mathrm{~cm}$ width and approx. $14 \mathrm{~cm}$ water depth. The stretches are $110 \mathrm{~cm}$ long, and the radii are $50 \mathrm{~cm}$ and $25 \mathrm{~cm}$ respectively (Fig. 1). Each channel is driven by an eccentric

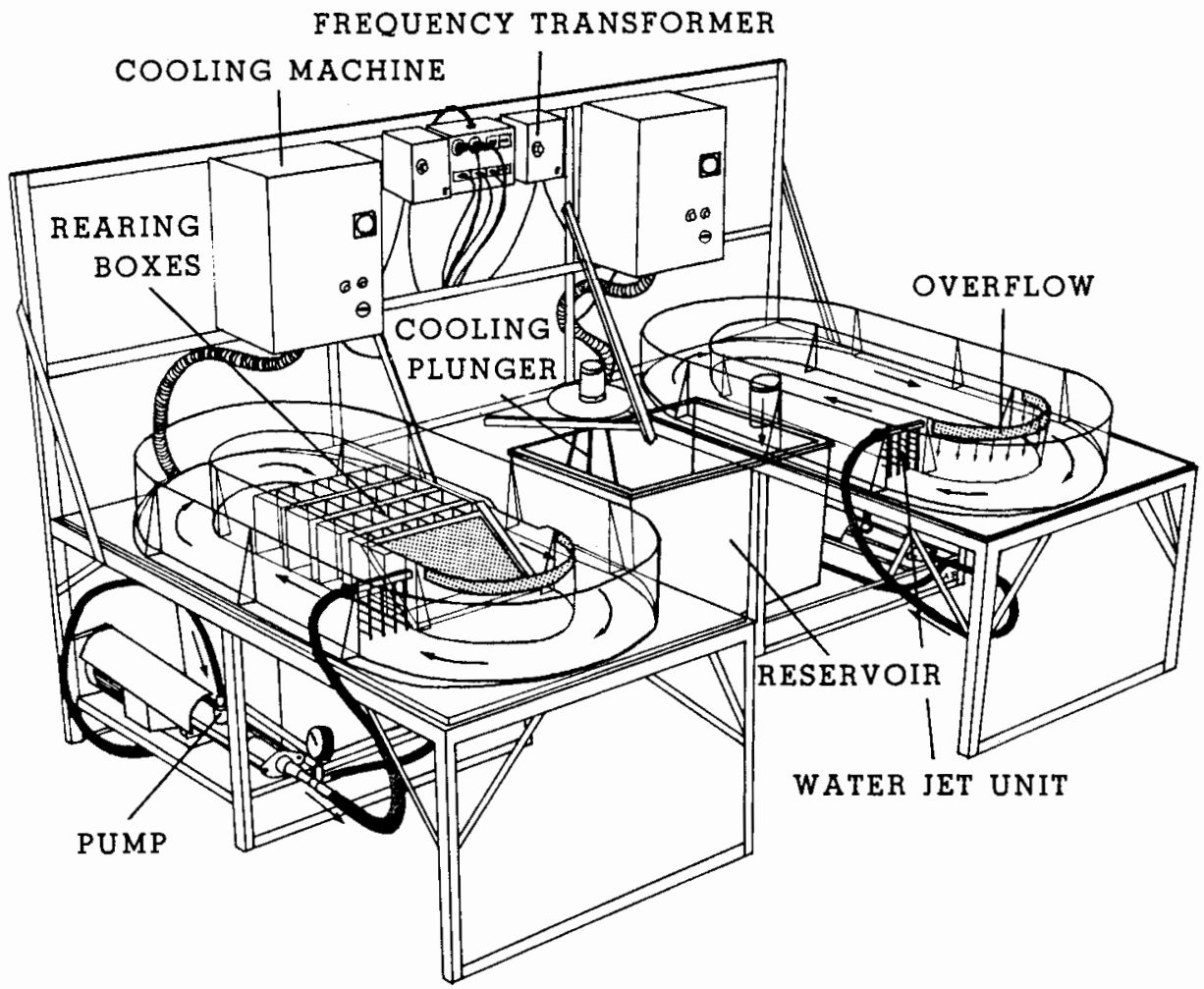

Figure 1. Semi-schematic representation of the flow channel (see text for explanation). 


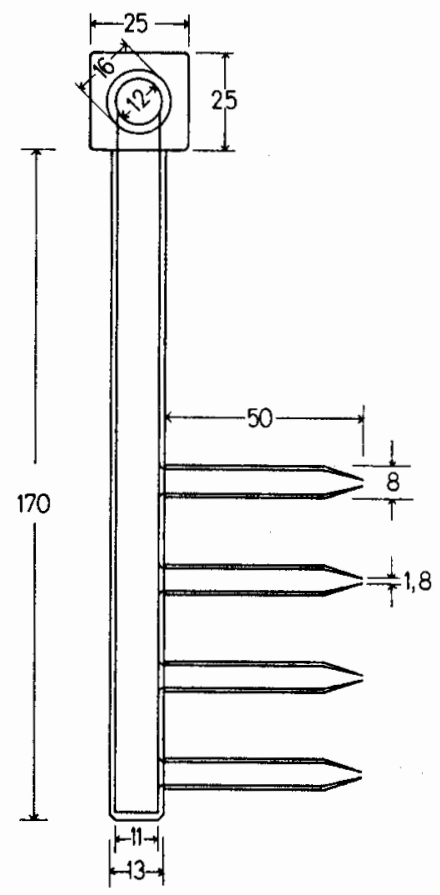

Figure 2. Cross-section of driving unit. Diameter of bores, edges etc. were designed in such a way so as to minimize turbulence and current resistance (all measures in $\mathrm{mm}$ ).

screw rotary pump and regulated by an infinitely variable frequency transformer. The transported water passes through a rubber hose and a distributor into four vertical pipes evenly distributed over the channel's cross section and located at the beginning of one of the stretches. The water flows out at high speed (up to $20 \mathrm{~m} / \mathrm{s}$ ) through four parallel foreward-directed nozzles of $2.5 \mathrm{~mm}^{2}$ orifice mounted every $25 \mathrm{~mm}$ on each pipe (Fig. 2). This impulse is relayed to the water in the channel and causes a current which can be regulated over a wide range by the motor's speed.

Depending on the type of operation, the pumped water which amounts to $1 / 20$ to $1 / 40$ of the waterflux in the channel (between 5 and $50 \mathrm{l} / \mathrm{min}$ ) reaches the center of the system over the channel's overflow on the inner side of one of the curves. Since the outlet is located in the middle of the opposite curve, a weak current is thereby also produced in the center of the channel and can be used for rearing running water animals. For the above mentioned experiments, four cages per channel, each divided into seven individual boxes and fitting exactly in the inner walls of the center, were set behind one another. After passing through the four cages, the water falls into the reservoir and is then sucked up again by the pump through a rubber hose.

In order to maintain the water chemism relatively constant, i.e. particularly to prevent accumulation of pollutants such as animals excrements, drinking water passed through an activated carbon filter can be added to the reservoir, thereby continuously renewing the water in the channel. 
The water is cooled by a cooling plunger and maintained at two set temperatures by a timer and two potentiometers which simulate the natural water's day/night rhythm.

For quantitative tests, where no animals are allowed to be lost, the channels can be covered by a net (mesh size $0.85 \mathrm{~mm}$ ) fastened on the upper edge by a "Velcro strip", and the outlets "closed" with a sack-shaped net $(0.24 \mathrm{~mm})$. In "front" of the rearingcages in the center of the channel, a net slide $(0.25 \mathrm{~mm})$ can be inserted, thereby preventing small organisms which pass the channel's overflow from entering the rearing-cages. Due to the risk of clogging, a relatively wide-meshed net $(0.65 \mathrm{~mm})$ was chosen for the overflow. At the far end of the stretch facing the drive unit, a sackshaped net $(0.24 \mathrm{~mm})$ can be inserted into a guide which will then filter all the circulating water. This is used for example when quantifying the population in the channels at the end of an experiment.

In order to minimize the negative effects of a possible power breakdown, the jet-powered units are also connected over a magnetic valve (closed under electrical current, but opening automatically in case of power failure) to the drinking water supply system. Thereby maintaining water flow and a certain cooling effect in the case of power failure. Two so-called waterflow-controllers were installed as an additional security measure. In the absence of water current, these interrupt (slightly delayed by a time-lag relay) the power supply of the pumps and magnetic valve, and at the same time trigger a technical alarm.

Unlike the linear flow channels [4, 6] and the circular systems with paddle wheel [5] or propeller drive [7], this channel construction largely avoids damage of drifting organisms. It is therefore very suitable for experiments requiring long-term rearing of the animals. Its arena-shaped design and "flexible" connected individual components, (for example hose instead of pipe), enable easy handling and a wide range of application possibilities. It can therefore be easily adapted to the requirements of specific experiments or, in case of defective individual components, these can rapidly be exchanged. By simply exchanging the pump connections during a breakdown of one cooler for example, it was possible to connect both channels. The shape of the channels and the type of drive used, produce a strong turbulence in the water which prevents exact determination of the hydraulic conditions. This channel system is therefore not suitable for experiments requiring such data (for example drift or transport of sedimentary material).

For more technical details and information on this flow channel see [3] or kindly contact the author.

\section{Summary}

Stream-dwelling organisms are physiologically dependent on current. Even if they are able to survive in still water for a limited period of time, their behaviour will most likely be seriously affected there. Consequently, laboratory investigations with running water animals should, in principle, only be carried out under flow conditions.

A flow channel, which has given good results for long-term rearing of benthic macroinvertebrates is described. It consists of two identical arena-shaped channels in which the current is produced by water jets, whereby damage to drifting animals is largely avoided. 


\section{RÉSUMÉ}

Les organismes des eaux courantes dépendent du courant. Même quand ils survivent dans des eaux stagnantes pendant une période limitée, on peut présumer que leur comportement y subira un effet préjudiciable. Par conséquent, des recherches en laboratoire avec des animaux d'eaux courantes doivent être réalisées en principe seulement sous des conditions de courant.

Une installation de canaux est décrite qui s'est éprouvée efficace pour d'expériances d'élevage des macroinvertébrés benthiques. Elle est composée de deux canaux annulaires (circulaires) identiques dans lesquels le courant est produit par des jets d'eau, ce qui évite en grande partie un endommagement des animaux dans la dérive.

\section{ZUSAMMENFASSUNG}

Fliesswasserorganismen sind auf Strömung angewiesen. Selbst wenn sie in stehendem Wasser eine gewisse Zeit überleben können, ist dort vermutlich ihr Verhalten stark beeinträchtigt. Daher sollten Laboruntersuchungen mit Fliesswassertieren prinzipiell unter Strömung durchgeführt werden.

Es wird eine Rinnenanlage beschrieben, die sich für Langzeithälterung von benthischen Makroinvertebraten gut bewährt hat. Sie besteht aus zwei identiscnen, arenaförmigen (zirkulären) Rinnen, in denen die Strömung durch Wasserstrahlen erzeugt wird, womit eine Beschädigung von driftenden Tieren weitgehend vermieden wird.

\section{REFERENCES}

1 Ambühl H.: Die Bedeutung der Strömung als ökologischer Faktor. Schweiz. Z. Hydrol. 21(2), 133--264 (1959).

2 Eglin S.: Die Besiedlung cines natürlichen unbelasteten Flusslaufes durch filtrierende Makroinvertebraten. Diplomarbeit am Inst. für Gewässerschutz und Wassertechnologie der ETH Zürich, 54 pp. (1983).

3 Frutiger A.: Untersuchungen zur Ökologie der rïuberischen Steinfliege Dimocras cephalotes Curt. (Plecoptera: Perlidae) in einem Fliessgewässer der schweizerischen Voralpen. Diss. ETH Nr. 7400,92 pp. (1983).

4 Ibseher L., Keller A.: Das «Rheodrom», eine neue Fliesswasser-Versuchsanlage. Schweiz. Z. Hydrol. 37. 187-192 (1975).

5 Petran M.: Ökologische Untersuchungen an Fliessgewässern über die Beziehung zwischen Makrobenthos, Substrat und Geschiebetrieb. Diss. Rhein. Friedrich-Wilhelms-Univ. Bonn, 158 pp. (1977).

6 Rüttimann M.: Autökologische Untersuchungen der Eintagsfliegenlarve Ecdyonurus venosus (Fabr.) (Ephemeroptera) unter besonderer Berücksichtigung der Aufwanderung. Diss. ETH Nr.6510, 68 pp. (1980).

7 Vogel S., LaBarbera M.: Simple flow tank for research and teaching. BioScience 28(10), 638-643 (1978).

Address of the author: Swiss Federal Institute for Water Resources and Watcr Pollution Control (EAWAG), CH-8600 Dübendorf, Switzerland. 